\title{
THE ECONOMIC VALUE OF RECREATIONAL BENEFIT OF AIK NYET NATURE TOURISM, KPHL RINJANI BARAT: AN APPLICATION OF THE TRAVEL COST METHOD
}

\author{
(Nilai Ekonomi Rekreasi Wisata Alam Aik Nyet, KPHL Rinjani Barat: \\ Aplikasi Metode Biaya Perjalanan)
}

\author{
Kresno Agus Hendarto ${ }^{1}$, Rubangi Al Hasan², Yumantoko², Ahmad Nur², dan Kuncoro Ariawan ${ }^{3}$ \\ 'Balai Litbang Teknologi Perbenihan Tanaman Hutan, Kementerian Lingkungan Hidup dan Kehutanan, \\ Jl. Pakuan-Ciheuleut 105, Tegallega, Bogor Tengah16129, Jawa Barat, Indonesia \\ E-mail: kresnoah@yahoo.com \\ ${ }^{2}$ Balai Litbang Teknologi Hasil Hutan Bukan Kayu, Kementerian Lingkungan Hidup dan Kehutanan, \\ Jl. Dharma Bakti No 7, Desa Langko, Lingsar, Lombok Barat83371, NTB, Indonesia \\ E-mail: rubhasan@yahoo.com; yumant@gmail.com; matnur2001@yahoo.com \\ ${ }^{3}$ Pusat Penelitian dan Pengembangan Sosial, Ekonomi, Kebijakan dan Perubahan Iklim, \\ Kementerian Lingkungan Hidup dan Kehutanan, Jl. Gunung Batu No.5, Bogor 16118, Indonesia \\ E-mail:k_ariawan@hotmail.comm
}

Received 16 November 2017, Revised 20 Maret 2019, Approved 2 April 2019.

\begin{abstract}
Good knowledge on economic value of a particular tourist destination is primarily fundamental for effective management policy formulation. In 2015, Aik Nyet Nature Tourism, which covers an area of approximately 9.08 hectare, is one of tourist destinations planned to receive donation from Provincial Government of West Nusa Tenggara (Pemprov NTB) for its improvement and development of facilities, infrastructures as well as capacity building for people around the tourism location. Using travel cost method, this study estimates consumers' surplus and economic benefits of recreational value in Aik Nyet before the realization of donation from Pemprov NTB. Consumers' surplus per individual per visit is estimated using data collected from survey. Data were collected by means of self-administered, paper-based questionnaire completed on-site during weekend and national holiday of August to October 2015. Using poisson regression, the travel costs (transportation cost, consumption cost, and location paid entrance fee) were considered in the study to explain the frequency of individual's visit to the tourist location. Results of the study show that that consumer surplus obtained by visitors is Rp2,557.158 per visit per individual and the economic recreational value before the realization of the government's financial support is approximately Rp9,333,627.70 per year.
\end{abstract}

Keywords: Economic value; travel cost method; Aik Nyet; KPHL Rinjani Barat.

\begin{abstract}
ABSTRAK
Pengetahuan yang baik tentang nilai ekonomi suatu lokasi wisata adalah dasar yang utama untuk memformulasikan kebijakan manajemen yang efektif. Pada tahun 2015, Taman Wisata Aik Nyet, yang luasnya lebih kurang 9,08 hektar, merupakan salah satu destinasi wisata yang direncanakan akan mendapat bantuan dari Pemerintah Provinsi Nusa Tenggara Barat (Pemprov NTB) untuk pembenahan dan perbaikan sarana prasarana serta peningkatan kapasitas masyarakat di sekitar lokasi wisata. Penelitian ini, dengan menggunakan travel cost methods, mengestimasi surplus konsumen dan nilai ekonomi dari manfaat rekreasi di lokasi Aik Nyet, sebelum dikucurkannya bantuan dari Pemprov NTB tersebut. Surplus konsumen per individu per kunjungan diestimasi menggunakan data yang diperoleh dari survei di lokasi wisata. Data dikumpulkan dengan pengisian angket mandiri, dan berbasis kertas. Angket disebarkan di lokasi wisata pada akhir minggu dan hari libur nasional pada bulan Agustus sampai dengan Oktober 2015. Dengan menggunakan regresi poisson, total biaya perjalanan (biaya tranportasi, biaya konsumsi, dan biaya masuk ke lokasi) dipertimbangkan dalam penelitian ini untuk menjelaskan frekuensi kunjungan individu ke lokasi wisata. Hasil menunjukan bahwa sebelum dikucurkannya bantuan terdapat
\end{abstract}


surplus konsumen sebesar Rp2.557,158 dan nilai ekonomi rekreasi dari Aik Nyet sebelum dikucurkannya bantuan adalah sekitar $\operatorname{Rp} 9.333 .626,70$ per tahun.

Kata kunci: Nilai ekonomi; metode biaya perjalanan; Aik Nyet; KPHL Rinjani Barat

\section{INTRODUCTION}

Forest Management Unit (Kesatuan Pengelolaan Hutan/KPH) is a forest management area that is functionally intended to be efficiently managed in order to be sustainable (Peraturan Pemerintah Nomor 6 Tahun 2007 tentang Tata Hutan dan Penyusunan Rencana Pengelolaan Hutan, Serta Pemanfaatan Hutan). KPH has been established to be a priority on National Development Program and is specified in the Strategic Plan of the Ministry of Forestry of 2010-2014. The commitment of the Provincial Government of West Nusa Tenggara (NTB) in supporting the development of KPH has been determined in 2009-2013 Medium-Term Development Plan of NTB and in 2009-2013 Strategic Plan of the Forestry Service of NTB, with the main performance indicator target of the operation of three units of KPH Model organizations (KPHL Rinjani Barat, 2016).

Based on the Forestry Minister's Decision Nomor SK.785/Menhut-II/2009, Kesatuan Pengelolaan Hutan Lindung (KPHL) Rinjani Barat, with the extent of approximately 40,983 hectare, has been determined to be the first KPH Model in the Province of NTB. The declaration is based on the proposal of the Province of NTB considering such facts as: (1) the area becomes the upper stream of rivers and water catchment area that supplies drinking water and public irrigation in four municipalities/regencies (Lombok Barat, Lombok Utara, Lombok Tengah and Mataram); and (2) it has fascinating natural tourist objects that supports the tourism program in NTB (Mukarom, 2015). Moreover, to build its institutional independence, since 29 December 2014 KPHL Rinjani Barat has been established as a local government's work unit of Satuan Kerja Perangkat Daerah (SKPD) based on the Peraturan Daerah Provinsi Nusa Tenggara Barat Nomor 13 Tahun 2014. One of the service functions of KPHL Rinjani Barat is opening investment opportunities to support the achievement of sustainable forest management.

In 2015, Aik Nyet, which had an area approximately 9.08 hectare, is one of tourist destinations in KPHL Rinjani Barat/ Lombok Barat Regency and was planned to obtain financial supports from the Provincial Government of NTB. Republika (2015) wrote that for the improvement and development of the facilities and infrastructures in 30 tourist destinations and the capacity building for people around the tourist location, the government has allocated Rp8.5 billion in its revised local budget and Rp10 billion in the state budget for seven municipalities/ regencies. The budget was allocated by the Provincial Government of NTB for tourist destinations which are not managed by investors (Kompas, 2015).

Applying travel cost method, this study aims to estimate the economic value of the recreational benefits in Aik Nyet before the realization of government's financial supports. By investigating the economic value before the realized financial supports, it is expected that in the next study the economic added value will obtain results from the realization of the financial support.

This study used TCM (Travel Cost Method) to estimate the economic value of recreational benefits while the previous studies used TCM method to estimate the economic value of the recreational benefits in a relatively 
extensive area (such as, island, lake); this study exclusively covered the area of 9.08 hectare. With such an extent of area, this study would expose and solve problems commonly found in relatively narrow areas through the elimination of time cost. Furthermore, this would be the first study estimating the recreational values of Aik Nyet.

\section{RESEARCH METHODS}

\section{A. Location and Time of Study}

This study was conducted in the recreational area of Aik Nyet, KPHL Rinjani Barat which is administratively located in Desa Buwun Sejati, Kecamatan Narmada, Kabupaten Lombok Barat.

Data were collected from August to October in 2015 on weekends and national holidays using on-site surveys. The challenge of on-site surveys is the collection of adequte information when respondents are performing inrecreational activities. In other words, there may be some rejections from respondents to be involved in this study. To reduce the problems, we provided incentive to the respondents in the form of ballpoints and keyholders cost of less than Rp10,000.00.

\section{B. Sampling Method}

The population of this study consists of visitors of the Aik Nyet. Sample was taken with purposive sampling. Purposive sampling refers to non-probabilistic sampling technique which fulfils particular criteria (Cooper \& Schindler, 2011). In line with the objective, the criteria that is included in the selection of respondents are: (1) adults; (2) good literacy; (3) one representative when visitors come in group; (4) willingness-to-get involved in the study. In brief, the samples were collected in the following ways: (1) observing visitors in location; (2) matching visitor's criteria to prior determined criteria; (3) questioning opinions of visitors using questionnaires based on scores of point 2 (from the prior determined

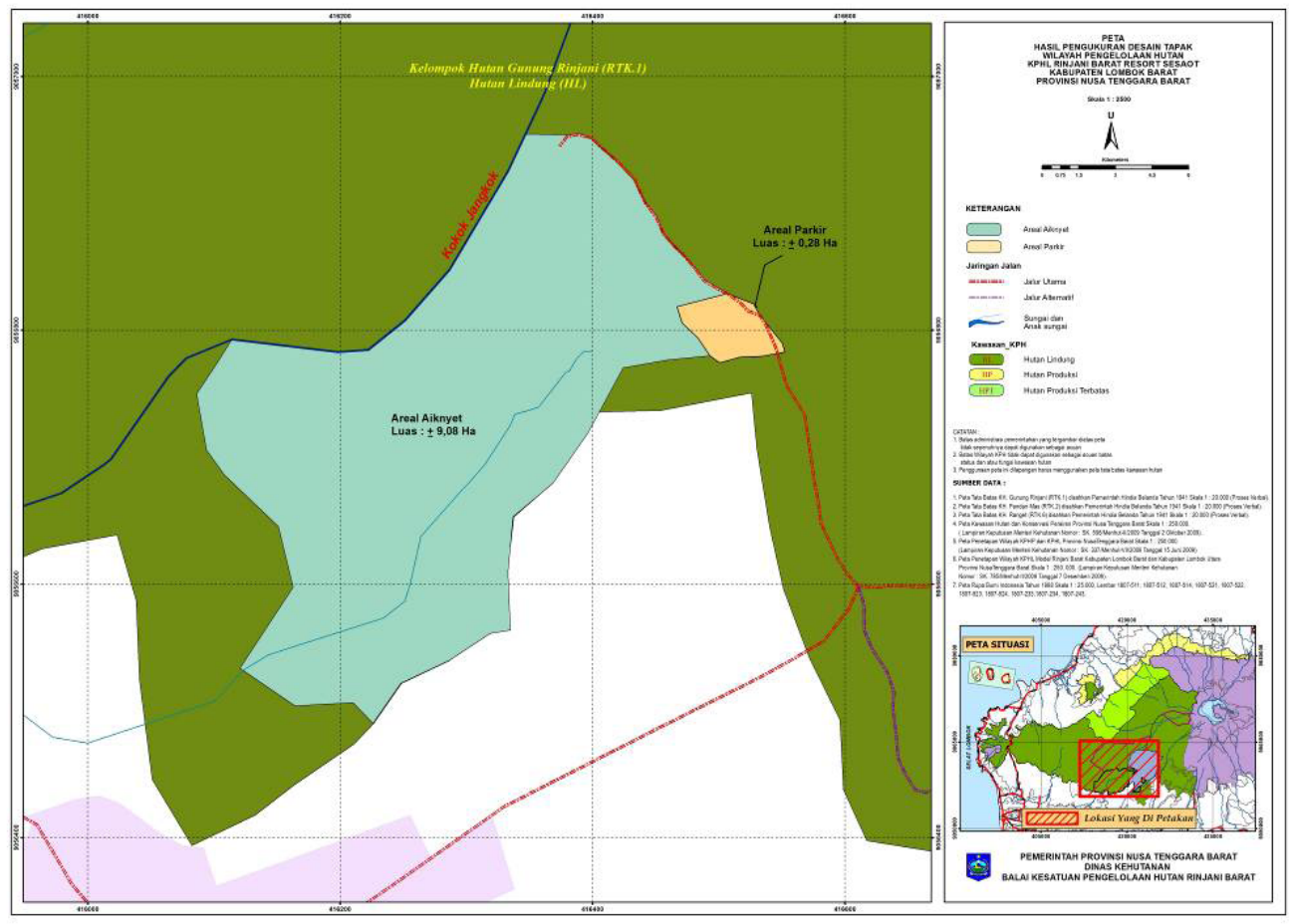

Source (Sumber): KPHL Rinjani Barat, 2015

Figure 1. Map of Aik Nyet, Resort of Sesaot

Gambar 1. Peta Aik Nyet, Wilayah Sesaot 
criteria).

Data obtained from the manager of the recreational area of Aik Nyet revealed that 3,650 visitors have visited the location annually. Implementing Slovin formula (Umar in Marpaung, 2011) the required minimum number of sample is 97.3 or 98 respondents. However, there is a limitation to carry out TCM method in determination of sample frame due to the multi trips visitors. Therefore, to meet the minimum number of sample, this study involved 200 respondents.

\section{Travel Cost Methods, Demand Function, and Consumer Surplus}

TCM is frequently used to assess outdoor recreation using environmental objects that are not marketed (Voke, Fairley, Willis, \& Masters, 2013). Salvo \& Signorello (2015) that has been initiated by Wood and Trice in 1958, Clawson in 1959, Davis in 1963, Mick and Myers in 1985, mention that there has been a serious global attempt to assess the economic value and benefits obtained by people from the use of natural capital for leisure time activities. Van Hove (2013) states that TCM bases on the premise that cost for tourist area uses can be considered as a proxy measure of the visitors' willingness-to-pay and accordingly is the customers' valuation to the tourist location. What is meant by the costs for tourist area uses include the implicit cost (such as meal and drink cost) and explicit cost (such as, vehicle rent, fuel, and entrance fee) spent by visitors.

Tourkolias et al. (2014) mention that there are three types of travel cost models: zonal travel cost model (ZTCM), individual travel cost model (ITCM/ TCM), and random utility travel cost model (RUTCM). However, of the three types, only two types of travel cost models are most frequently used; i.e. cost model and individual travel cost model. Zonal travel cost model uses total number of travels to location relative to the population in a particular zone as the dependent variable (see, for example: Jala \& Nandagiri, 2015;
Isnan, 2016; Pirikiya, Amirnejad, Oladi, \& Solout, 2016; Jones, Yang, \& Yamamoto, 2017); while individual travel cost model uses total number of visit per year as the dependent variable (Armbrecht, 2014). Compared to ZTCM, estimated using of TCM has some advantages (Ha, 2007). They are: (1) TCM resembles the conventional method used by economists to estimate economic value based on market price, (2) TCM estimation bases on what visitors have performed instead of what visitors will do in a hypothetic situation (Bell \& Leeworthy, 1990); and (3) almost similar to previous point, TCM estimation relies on the actual rather than optional situations (Ville, Marjo, \& Pouta, 2012).

In TCM, the two important bases of estimation are demand functions and consumer surplus. The law of demand requires that in case of ceteris paribus demand for particular goods will decline when the price increases; in other words, the law of demand describes an inverse relationship between price and quantity demanded of good; while demand function is the graph describing the relationship between goods' price and the total goods demanded (Mankiw, Quah, \& Wilson, 2014). Of that definition, it is clear that the characteristics of demand function are that it: (1) has negative slope (2) lies in quadrant 1, because it does not have negative values.

Another important aspect is consumer surplus. Consumer surplus is the difference between total utility enjoyed by consumers from consuming some particular goods and total expenses spent by consumers to obtain some particular goods (Boediono, 2013). Total utility and total expenses are assessed in money. Consumer surplus is closely associated to demand curve for particular goods or services (Mankiw et al., 2014). This is clearly explained in detail in Figure 2.

Consumer surplus is an area above price and below demand curve. In panel (a), consumer surplus at price $\mathrm{P} 1$ is the extent of triangle $\mathrm{ABC}$. The question is then what will happen if the price decreases in panel (B), the 
(a) Consumer surplus at price $P_{1}$

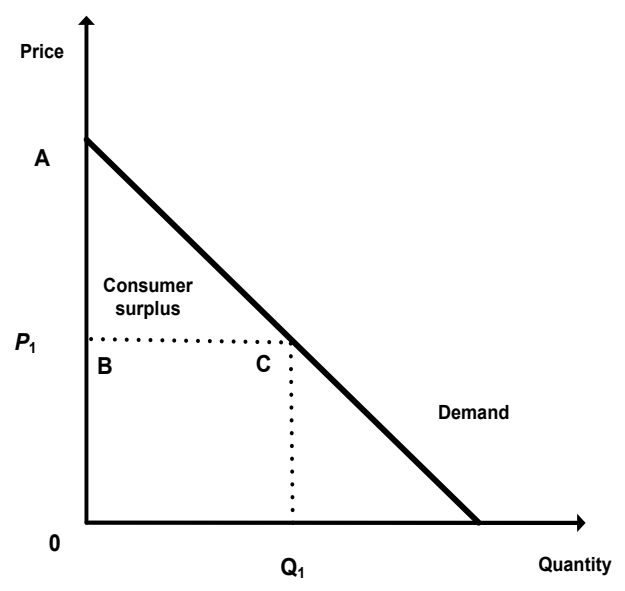

(b) Consumer surplus at price $P_{2}$

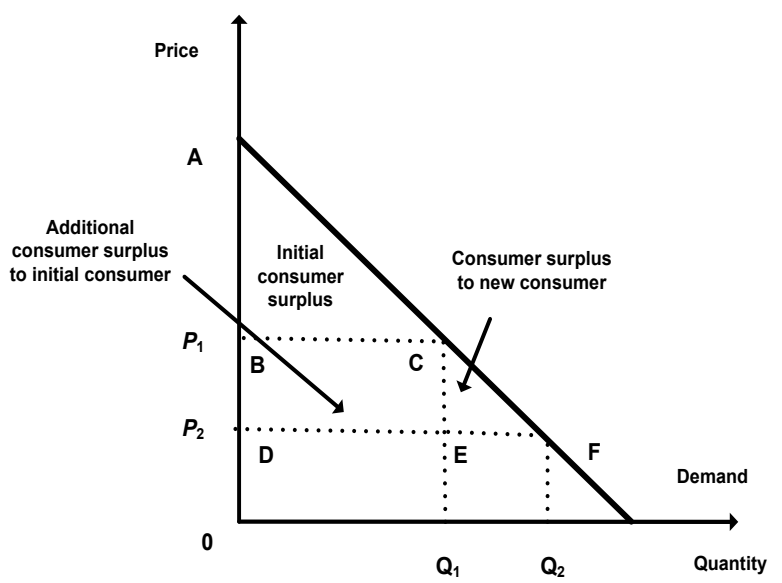

Source (Sumber): Mankiw et al. (2014)

Figure 2. Way of how price affects consumer surplus Gambar 2. Bagaimana harga memengaruhi surplus konsumen

price decreases from $\mathrm{P} 1$ to $\mathrm{P} 2$, that consumer surplus shifts to ADF. In other words, when price decreases, consumer surplus will increase. Increase of consumer surplus which is due to the price decrease is represented by the extent of BCDF.

The final objective of this study using Travel Cost Methods is to estimate welfares deriving from utilization of tourist location. Therefore, it is clear that the equation of total demand function has to be associated to utility maximization (Kealy \& Bishop, 1986).

The general formulation of demand for recreation to result in TCM for one visiting to a tourist location proposed by Hanley \& Spash (1994); Voke et al. (2013) is:

$$
\mathrm{TC}_{\mathrm{ij}}=\mathrm{DC}_{\mathrm{ij}}+\mathrm{OC}_{\mathrm{ij}}+\mathrm{F}_{\mathrm{i}}
$$

where $\mathrm{i}=1 \ldots \mathrm{n} ; \mathrm{j}=1 . . \mathrm{m}$ (TC is total travel cost, DC is distance cost, OC is time cost and $F$ is paid entrance fee).

In practice, there are a number of problems in the use of TCM. Some of them are the treatments of time, of multiple site visitors, and of overseas visitors (Fleming \& Cook, 2008).

Since the initiation, the involvement of time cost in TCM has become a problem. In general, time cost consists of the time needed to travel from the original place to recreational location, the time spent in the recreational location, and the time spent to travel from the recreational location to the original place. McConnell (1999) suggests that the time, like money, limits one's decision on recreational activities.

The main reason of involving time cost is that it is considered as rare commodity, opportunity cost of time will affect price and demand elasticity, and also will reduce the economic value of a recreational location. In other words, when someone decides to visit a particular recreational location, he will balance the spent cost and the enjoyed benefits and compare it to other goods that can be obtained with the equal cost and time (Álvarez-farizo, Hanley, \& Barberán, 2001).

Several studies have developed various alternative approaches in valuating the time cost. The first alternative is that time cost can be approached from the wage rate or $1 / 3$ of the wage rate. It is assumed that: (a) individuals would trade time spent in recreation for time spent in work; and (b) that work time itself is 
neither to be liked nor disliked. The second alternative is that time cost can be approached by a labor supply model. However, in practice, both alternatives can result in difficulties (Lew \& Larson, 2005). These difficulties are particularly found in the calculation of formal worker respondents. Respondents (particularly in Aik Nyet) have fixed working hours, weekend holidays, and additional leaves. The third alternative is that time cost can be approached by stated reference data. Although the third alternative is relatively prospective, it still bears some problems of how to add other locations preference questions in the questionnaires (Fleming \& Cook, 2008). Due to the difficulties, in this study time cost in the model is not included. We excluded the time cost because the survey is conducted on weekend holidays and/or national holidays. Beside that, Aik Nyet is preferred by visitors from other recreational sites around it.

Another difficulty in the use of TCM is that it is assumed that only one location is visited per trip. Because there is only one place visited, the visitors solely spend the cost for that place. The further question is what happen if they have multiple trips. This will result in a biased determination of which cost is excluded from one location, and which another is excluded from another location. One of the solutions for this problem is calculating only some parts of the travel cost. However, this solution will weaken the procedure of trip cost since it does not match the assumed cost trip cost (Beal in Fleming \& Cook, 2008). Therefore, this study excludes the visitors with multiple trips in the analysis, by questioning them some filter questions in the questionnaires.

Next problem is how to treat foreign visitors. This is another difficulty in the application of TCM. Since it is assumed that the impact on the consumers is relatively low; some researchers eliminate all foreign visitors from their sample, for example Carr \& Mendelsohn (2003), Prayaga, Rolfe, \& Sinden (2006), Fleming \& Cook (2008). This study takes the same approach (using some filter questions), it means that it is eliminating foreign visitors from the analysis.

Therefore, it could be determined that recreational demand model that maximizes individual utility to the tourist location is:

$\mathrm{Y}_{\mathrm{i}}=\mathrm{f}\left(\mathrm{C}_{\mathrm{i}}\right)$;

where: $\mathrm{Y}=$ total visit in the past 1 year; $\mathrm{C}_{\mathrm{i}}=$ travel cost to visit location, which is the combination of distance cost and paid entrance fee.

Based on the model, the following hypothesis is proposed:

$\mathrm{H}_{1}$ : The higher the travel cost spent by visitors, the fewer visits would be performed by visitors.

\section{Measurement}

Structured questions in the questionnaires were used to survey the visitors. The questionnaires consist of two parts. The first is questioning about general information of the respondents. The second is investigating the travel cost paid by the respondents. The operational definition of the study is presented in Table 1.

In the first part of the questionnaires, the questions investigate respondents' profile and the place from which they acquire information about the tourist location. The first part ends with filter question. The second part of the questionnaires examines the frequency of respondents' visit to the location in the past 1 year and the travel cost paid from their place to the tourist location. The travel cost refers to the currently paid cost. Items of questions are modified from the previous study conducted by (Nur, 2014).

The questionnaires were designed to be self-administered questionnaires. Zikmund \& Babin (2016) states that self-administered questionnaires are challenging to researches since respondents' answers depend on the clarity of the written words rather than on the interviewers' capability. Since the questions of total visit and travel cost are open-ended, then the validity and reliability are applied 
using pilot test. In other words, when the questionnaires are modified, the initial step taken is implementing a pilot test. Pilot test is conducted to identify: (1) whether or not ambiguous words present; (2) whether or not the instructions are understandable; (3) whether or not respondents would find difficulties to answer; and (4) the time demanded by the respondents to complete the questionnaires. Pilot test is conducted for few respondents (six respondents).

Having been revised bases on the results of the pilot test, the questionnaires are distributed to respondents.

\section{E. Data Analysis}

Windle \& Rolfe (2013) state that initially, TCM is applied with a standard regression technique to identify the correlation between the number of visit frequency (dependent variable) and travel cost and population characteristics (independent variables). Count data model or poisson regression is commonly employed at present time, where the independent variables are the count data represents discrete events. Poisson regression model is a statistic method used to analyze the correlation between countable response variables (count data) and one or more explanatory variables (Irwan \& Sari, 2013). The response variable in poisson regression technique is different from that in standard regression. In poisson regression, the response variable is probably non-negative and integervalued density. Distribution of count data is also characterized by the little amount of data concentration (for example one or two) and left skew. The two characteristics represent general individual recreation behavior.

It is assumed that in poison regression, the mean and variation of dependent variables have the same value (Wei \& Lovegrove, 2013). Therefore, in poison regression, there may be over dispersion and/or under dispersion. Listiani (2010) mentions that over dispersion and/or under dispersion occur when the variant is larger or smaller than the mean. Further, it is stated that Negative Binomial Model and/or Generalized Poisson Model (GPM) may deal with this problem of over/under dispersion, in condition that the data do not have many zeros. Since poisson regression model resembles GPM, GPM is applied in this study. The general model of GPM can be written as it follows:

or

h $E\left(y_{i} \mid x_{i}\right)=\mathrm{h}\left(\mu_{i}\right)=\eta_{i}=\beta_{0}+\beta_{1} x_{i 1}+\beta_{2} x_{i 2}+\ldots+\beta_{k} x_{k}$

Steps of data analysis are presented below. $\mu_{i}=\exp \left(x_{i}^{T} \beta\right)=\exp \left(\beta_{0}+\beta_{1} x_{i 1}+\beta_{2} x_{i 2}+\ldots+\beta_{k} x_{k}\right)$

1. Estimating the demand function from Aik Nyet with poisson regression and testing the hypothesis.

2. Calculating the value of consumer surplus per individual at each level of visit frequency with the formula of

Windle \& Rolfe (2013).

3. Calculating the probability of visitor sample at each level of visit frequency with the formula of

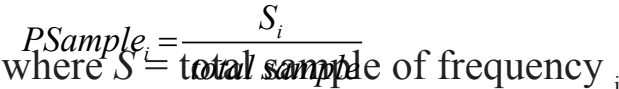

4. Calculating the probability of individual visitor at each level of visit frequency with the formula of

PIndividu $u_{i}=$ PSample $_{i} \times$ total visitors

5. Calculating the willingness-to-pay (WTP) of Individuals at each level of frequency.

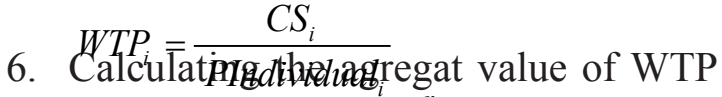
with the formula of $\sum_{i=1}^{n} W T P_{i}$

7. Calculating the economic value of recreational benefit with the formula of

$\sum_{i=1}^{n} W T P_{i} x$ total visitors 


\section{RESULTS AND DISCUSSIONS}

\section{A. Profile of Respondents}

The minimal sample required is 98 . To anticipate the unexpected possibilities, we doubled the number of the questionnaires up to approximately 200 to the location of study. Of the 200 distributed questionnaires, 147 were eligible for further analysis (response rate of $73.5 \%$ ). Some of data in the questionnaires could not be analyzed because: (1) some questionnaires were missing; (2) the items of the answers related to the variable of this study are not completed; and (3) when it is completed, respondents' completion is outlier. Gudono (2011) states that outlier may result in bias, and regression coefficient estimate will be biased to the outlier. Outlier data are eliminated by counting the data (standardized data). When data standardization is over 2.5 or less than 2.5 , it is expected that the data are outlier so that they are excluded from the analysis (Santoso, 2017).

Table 2 shows that respondents' profile represents that: (1) more than half of respondents are male; (2) more than half of respondents are senior high school graduates; (3) most of respondents domiciled in Mataram; and (4) most of respondents are in the age range of 20 and 30 years.

\section{B. Generalized Poisson Regression}

Results of generalized poisson regression analysis for the variable can be seen in Table 3:

Table 3 shows that cost variable has significant effect on variable of total visit. Results of model analysis for Aik Nyet can be written as it follows:

$$
\mu \text { Tot_Vis }=\exp \left(1.072-0,000002002 T_{-} \text {Cost }\right)
$$

From the aforementioned model, it could be stated that the predicted result of TCM is significant at $\alpha=5 \%$ (p-value $<0.05)$. The Poisson's regression model implies that when there is no travel cost, then, the total of total visit is $\exp (1.072)=2.92=3$. Each additional of 1 unit of travel cost will reduce the total visit by $\exp (0.000002002)=0.999=1$. This is in line with the demand and supply theory.

Table 2. Respondents demographic profile $(n=147)$

\begin{tabular}{|c|c|c|c|}
\hline Variable ( Variabel) & $\begin{array}{l}\text { Percentage } \\
\text { (Persentase) }\end{array}$ & $\begin{array}{l}\text { Variable } \\
\text { (Variabel) }\end{array}$ & $\begin{array}{l}\text { Percentage } \\
\text { (Persentase) }\end{array}$ \\
\hline Gender (Jender) & \multicolumn{2}{|c|}{ Age } & \\
\hline Male (Laki-laki) & 72.79 & $<20$ & 43.54 \\
\hline \multirow[t]{4}{*}{ Female (Perempuan) } & \multirow[t]{4}{*}{27.21} & $20-30$ & 44.90 \\
\hline & & $31-40$ & 7.48 \\
\hline & & $41-50$ & 4.08 \\
\hline & & $>50$ & - \\
\hline \multirow{2}{*}{$\begin{array}{l}\text { Education (Pendidikan) } \\
\quad \text { No School (Tidak sekolah) }\end{array}$} & \multicolumn{2}{|c|}{ Domiciled } & \\
\hline & 2.04 & Lombok Barat & 22.05 \\
\hline Primary School (Sekolah Dasar) & 4.76 & Lombok Tengah & 3.15 \\
\hline \multicolumn{3}{|l|}{ Junior High School (Sekolah } & \\
\hline Lanjutan Tingkar Pertama) & 15.65 & Lombok Timur & 7.09 \\
\hline \multicolumn{3}{|l|}{ Senior High School (Sekolah } & \\
\hline Lanjutan Tingkat Atas) & 64.63 & Lombok Utara & 28.35 \\
\hline \multirow[t]{2}{*}{ University (Perguruan Tinggi) } & 12.93 & Mataram & 37.01 \\
\hline & & $\begin{array}{l}\text { Outside of Lombok } \\
\text { Island }\end{array}$ & 2.35 \\
\hline
\end{tabular}

Tabel 2. Profil demografi responden $(n=147)$

Source (Sumber): Primary data (Data primer). 
Table 3. Parameter estimation

Tabel 3. Estimasi parameter

\begin{tabular}{lrrrrr}
\hline Parameter & \multicolumn{1}{c}{$\begin{array}{c}\text { Std. Error } \\
\text { (Parameter) }\end{array}$} & \multicolumn{3}{c}{ Hypothesis Test (Pengujian hipotesis) } \\
\cline { 4 - 6 } (Intercept) & 1,072 & (Kesalahan standar) & Wald Chi-Square & $\mathrm{df}$ & Sig. \\
T_Cost & $-2.002 \mathrm{E}-6$ & 0.1004 & 113,937 & 1 & 0,000 \\
$($ Scale $)$ & $1^{\mathrm{a}}$ & $9,3496 \mathrm{E}-7$ & & 1 & 0,032 \\
\hline
\end{tabular}

Dependent Variable: Total_Visit, Model: (Intercept), T_Cost a. Fixed at the displayed value.

Source (Sumber): Primary data (Data primer).

Table 4. Results of consumer surplus and willingness-to-pay estimates

Tabel 4. Hasil perhitungan surplus konsumen dan kesediaan untuk membayar

\begin{tabular}{cccccc}
\hline No & $\begin{array}{c}\text { Beta of Travel } \\
\text { Cost } \\
\text { (Koefisien beta } \\
\text { biaya perjalanan) }\end{array}$ & $\begin{array}{c}\text { Consumer } \\
\text { Surplus/ } \\
\text { Rp) (Surplus } \\
\text { Konsumen/ } \boldsymbol{R} \boldsymbol{p}\end{array}$ & $\begin{array}{c}\text { Probability } \\
\text { (Kemungkinan) }\end{array}$ & $\begin{array}{c}\text { Probability } \\
\text { x estimated } \\
\text { number of } \\
\text { total visitors } \\
\text { (Kemungkinan } \boldsymbol{x} \\
\text { pengunjung total) }\end{array}$ & $\begin{array}{c}\text { Willingness- } \\
\text { to-Pay/Rp } \\
\text { (Kesediaan untuk } \\
\text { membayar/Rp }\end{array}$ \\
\hline 1 & $2.002 \mathrm{E}-06$ & $499,500.50$ & 0.34 & 1,217 & 410.558 \\
2 & $2.002 \mathrm{E}-06$ & $499,500.50$ & 0.23 & 844 & 591.673 \\
3 & $2.002 \mathrm{E}-06$ & $499,500.50$ & 0.12 & 447 & $1,117.604$ \\
4 & $2.002 \mathrm{E}-06$ & $499,500.50$ & 0.31 & 1,142 & 437.323 \\
\hline
\end{tabular}

Source (Sumber): Primary data (Data primer).

\section{Consumer Surplus and Economic Value of Recreation}

Calculation of consumer surplus of visit per individual and willingness-to-pay can be seen in Table 4.

Table 4 shows that for Aik Nyet, the value of consumer surplus is $\mathrm{Rp} 2,557.158$ per visit per individual. Economic value is the maximum amount that an individual is willing to sacrifice goods or services for other goods or services (Ichwandi in Nur, 2014). With the estimate of total annual number of visitor of Aik Nyet is approximately 3,650 units, the calcualted economic value of recreational benefit is: Rp2,557.158 x 3,650= Rp9,333,626.70 per year.

\section{Discussion}

Consumer surplus can be easily calculated when the demand curve has been found (Pindyck \& Rubinfield, 2012). The demand curve shows the correlation between total demand and price. Demand curve bases on the demand law which states that in case of ceteris paribus, the total demand for a particular product will diminish when the price increases (Mankiw et al., 2014).

The initial step of analysis is determining the recreational demand curve. One of the characteristics of recreational demand curve is that the achievable utility level may change due to the shift along the curve. The lower the price of particular products, the higher the utility would be (Pindyck \& Rubinfield, 2012). This describes that when the price of 
a praticular product decreases, consumers' purchase power incrases.

Economic theory suggests that income (wage) is an important factor that may shift demand curve for all purchases or activities. In TCM model, several researchers use wage rate as the proxy of time cost. However, empirically, for several years, the correlation between wage rate and number of visits to the tourist location in TCM is still an enigma (Blaine, Lichtkoppler, Bader, Hartman, \& Lucente, 2015). A lot of studies show negative correlation; some others show zero effect. This is clearly described by Weiler (2006), Prayaga et al. (2006), Taylor, Mckean, \& Johnson (2010), Mckean, Johnson, \& Taylor (2012), and Hendarto, Al-Hasan, Yumantoko, \& Nur (2018). Consequently, this study eliminates time cost from the model, which is similar to the study conducted by Prayaga et al. (2006) and Loomis \& Ng (2012).

Therefore, the proposed hypothesis of the study is "the higher the travel cost paid by visitors, the fewer the visitors would be". Results of the test suggest that the hypothesis is accepted. In other words, the hypothesis of this study is in line with the data collected.

When the recreation demand function is obtained, consumer surplus is estimated. Results of estimation reveal that the value of visitors' WTP is Rp2,557.158 per visit per individual. This implies that visitors are willing to pay additional Rp2,000.00 higher than the rate specified in the paid entrance fee. Meanwhile, the economic value of recreation benefits in Aik Nyet before the realization of the financial support from the provincial government is Rp9,333,626.70 annually.

\section{CONCLUSIONS AND RECOMMENDATIONS}

\section{A. Conclusion}

The objective of this study is to identify whether or not there is a consumer surplus in the recreational area of Aik Nyet and estimate the economic value of the recreational benefits in Aik Nyet before the granted aid from the Provincial Government of NTB. The aid is focused on the recreational locations which are not managed by investors. Results of the analysis suggest that the visitors of Aik Nyet obtain the consumer surplus of Rp2,557.158 per visit per individual and the economic value of the recreational area of Aik Nyet is Rp9,333,626.70 per year.

\section{B. Recommendations}

This study has some limitations. First, it does not include variables of social economy and biophysic in the TCM model. Further research should include social, economic and biophysic variables (such as age, education level, gender, location attractiveness, location uniqueness) into the model. Second, economic value in this study is estimated before the realization of financial support from the provincial government. It is advisable to estimate the economic value when the financial support has been realized.

\section{ACKNOWLEDGEMENTS}

The authors gratefully acknowledge the data collected by I Made Widnyana, Alpian, Dewi, and Yuni from Balai Penelitian Teknologi Hasil Hutan Bukan Kayu Mataram; comments made by Shine Pintor Siolemba Patiro from Gadjah Mada University, Siti Latifah and Markum from Mataram University, and also the anonymous reviewers for their comments on this article.

\section{DAFTAR PUSTAKA}

Álvarez-farizo, B., Hanley, N., \& Barberán, R. (2001). The value of leisure time: A contingent rating approach. Journal of Environmental Planning and Management, 44(5), 681-699. https://doi. org/10.1080/09640560120079975

Armbrecht, J. (2014). Use value of cultural experiences: A comparison of contingent valuation and travel cost. Tourism Management, 42, 141-148. https://doi.org/10.1016/j.tourman.2013.11.010 
Bell, F. W., \& Leeworthy, V. R. (1990). Recreational demand by tourists for Saltwater Beach Days'. Journal of Environmental Economic and Management, 18(3), 189-205.

Blaine, T. W., Lichtkoppler, F. R., Bader, T. J., Hartman, T. J., \& Lucente, J. E. (2015). An examination of sources of sensitivity of consumer surplus estimates in travel cost models. Journal of Environmental Management, 151, 427-436. https://doi.org/10.1016/j.jenvman.2014.12.033

Boediono. (2013). Ekonomi mikro (2 ${ }^{\text {nd }}$ ed.). Yogyakarta: BPFE.

Carr, L., \& Mendelsohn, R. (2003). Valuing coral reefs: A travel cost analysis of the Great Barrier Reef. Journal of the Human Environment, 32(5), 353-357.

Cooper, D. R., \& Schindler, P. S. (2011). Business research methods ( $11^{\text {th }}$ ed.). Singapore: McGraw-Hill International Edition.

Fleming, C. M., \& Cook, A. (2008). The recreational value of Lake McKenzie, Fraser Island: An application of the travel cost method. Tourism Management, 29, 1197-1205.

Gudono. (2011). Analisis data multivariat. Yogyakarta: BPFE.

Ha, I. S. (2007). Recreational demand for a Gulf Coast tourism destination. Jourmal of Economics and Economic Education Research, 8(1), 51-65.

Hanley, N., \& Spash, C. L. (1994). Cost-benefit Analysis and the Environment. Massachusetts: Edward Elger.

Hendarto, K. A., Al-Hasan, R., Yumantoko; \& Nur, A. (2018). Estimating entrance fee of Sendang Gile water fall for state based recreation. Jurnal Ekonomi Kuantitatif Terapan, 11(2), 200-208.

Irwan, \& Sari, D. P. (2013, November). Pemodelan regresi poisson dan binomial negatif dan pada kasus kecelakaan kendaraan bermotor di lalu lintas Sumatera Barat. Paper presented at The National Seminar Matematika dan Pendidikan Matematika dengan tema "Penguatan Peran Matematika dan Pendidikan Matematika untuk Indonesia yang Lebih Baik, Yogyakarta: Universitas Negeri Yogyakarta.

Isnan, W. (2016). Harga optimal tiket masuk wisata alam Bantimurung, Sulawesi Selatan. Jurnal Penelitian Sosial dan Ekonomi Kehutanan, 13(3), 155-163.

Jala, \& Nandagiri, L. (2015). Evaluation of economic value of Pilikula Lake using travel cost and contingent valuation methods. Aquatic Procedia, 4, 1315-1321. https://doi. org/10.1016/j.aqpro.2015.02.171

Jones, T. E., Yang, Y., \& Yamamoto, K. (2017). Assessing the recreational value of world heritage site inscription: A longitudinal travel cost analysis of Mount Fuji climbers. Tourism Management, 60, 67-78. https://doi. org/10.1016/j.tourman.2016.11.009

Kealy, M. J., \& Bishop, R. C. (1986). Theoretical and empirical specifications issues in travel cost demand studies. American Journal of Agricultural Economic, 68(3), 660-667.

Kompas. (2015). Pemprov NTB benahi destinasi wisata. Retrieved April 1, 2019, from https:// travel.kompas.com/read/2015/01/20/1053002/ Pemprov.NTB.Benahi.Destinasi.Wisata.

KPHL Rinjani Barat. (2015). Rencana desain tapak kawasan hutan Sesaot. Lombok: KPHL Rinjani Barat.

KPHL Rinjani Barat. (2016). Latar belakang KPHL Rinjani Barat. Lombok: KPHL Rinjani Barat.

Lew, D. K. ., \& Larson, D. M. (2005). Accounting for stochastic shadow values of time in discretechoice recreation demand models. Journal of Environmental Economics and Management, 50, 341-351.

Listiani, Y. (2010). Pemodelan regresi generalized poisson pada faktor-faktor yang mempengaruhi angka kematian bayi di Jawa Timur. (Thesis). Surabaya: Institut Teknologi Sepuluh Nopember.

Loomis, J., \& Ng, K. (2012). Comparing economic values of Trout Anglers and Nontrout Anglers in Colorado's Stocked Public Reservoirs. North American Journal Fisheries Management, 32(2), 202-210. https://doi.org/10.1080/02755 947.2012 .662089

Mankiw, N., Quah, E., \& Wilson, P. (2014). Principles of economics: An Asia edition ( $2^{\text {nd }}$ ed.). Singapore: Cengage.

Marpaung, G. N. (2011). Analisis faktor-faktor yang mempengaruhi konsumen terhadap permintaan perumahan. JEJAK, 4(2), 125-134.

McConnell. (1999). Household labor market choices and the demand for recreation. Land Economics, 75(3), 466-477.

Mckean, J. R., Johnson, D., \& Taylor, R. G. (2012). Three approaches to time valuation in recreation demand: A study of the Snake River recreation area in eastern Washington. Journal of Environmental Management, 112(2012), 321-329. https://doi.org/10.1016/j. jenvman.2012.08.017

Mukarom, M. (2015). KPH Rinjani Barat selayang pandang (I. Berliani, H.; Hardiyanto, G.; Gaban, F.; Ardiansyah, Eds.). Jakarta: Kemitraan.

Nur, A. (2014). Valuasi ekonomi objek wisata Taman Rekreasi Wiladatika dengan metode biaya perjalanan. (Master's Thesis). Depok: Universitas Indonesia. 
Ovaskainen, Ville; Neuvonen, Marjo; Pouta, E. (2012). Modelling recreation demand with respondent-reported driving cost and stated cost of travel time: A Finnish case. Journal of Forest Economics, 18, 303-317. https://doi. org/10.1016/j.jfe.2012.06.001

Peraturan Daerah Provinsi Nusa Tenggara Barat Nomor 13 Tahun 2014 tentang Perubahan Kedua atas PERDA Nomor 3 Tahun 2009 tentang Organisasi dan Tata Kerja Lembaga Lain Sebagai Bagian dari Perangkat Daerah Provinsi Nusa Tenggara Barat.

Peraturan Pemerintah Nomor 6 Tahun 2007 tentang Tata Hutan dan Penyusunan Rencana Pengelolaan Hutan, Serta Pemanfaatan Hutan.

Pindyck, R.S.\& Rubinfield, D..(2012). Microeconomics ( $8^{\text {th }}$ ed.). London: Pearson.

Pirikiya, M., Amirnejad, H., Oladi, J., \& Solout, K. A. (2016). Determining the recreational value of forest park by travel cost method and defining its effective factors. Journal of Forest Science, 9, 399-406. https://doi.org/10.17221/12/2016JFS

Prayaga, P., Rolfe, J., \& Sinden, J. (2006). A travel cost analysis of the value of special events: Gemfest in Central Queensland. Tourism Economics, 12(3), 403-420. https://doi. org $/ 10.5367 / 000000006778493592$

Republika. (2015). NTB revitalisasi 30 paket destinasi wisata. Retrieved July 25, 2016, from http:// www.republika.co.id/ berita/gaya-hidup/ travelling/15/06/18/nq447j-ntb-revitalisasi-30$\% 0$ Apaket-destinasi-wisata

Salvo, M. De, \& Signorello, G. (2015). Non-market valuation of recreational services in Italy: A meta-analysis. Ecosystem Services, 16, 47-62. https://doi.org/10.1016/j.ecoser.2015.10.002

Santoso, S. (2017). SPSS statistik multivariant. Jakarta: Elex Media Komputindo.

Taylor, R. G., Mckean, J. R., \& Johnson, D. (2010). Measuring the location value of a recreation site. Western Agricultural Economics Association, 35(1), 87-104.
Tourkolias, Christos; Skiada, Theodora; Mirasgedis, Sebastian; Diakoulaki, D. (2014). Application of the travel cost method for the valuation of the Poseidon Temple in Sounio, Greece. Journal of Cultural Heritage, 16, 567-574. https://doi. org/10.1016/j.culher.2014.09.011

VanHove, N. (2013). Consumer surplus and macro valuation of tourism projecy. Poznan University of Economics Review, 13(4), 46-66.

Voke, M., Fairley, I., Willis, M., \& Masters, I. (2013). Ocean \& coastal management economic evaluation of the recreational value of the coastal environment in a marine renewables deployment area. Ocean and Coastal Management, 78, 77-87. https://doi. org/10.1016/j.ocecoaman.2013.03.013

Wei, F., \& Lovegrove, G. (2013). An empirical tool to evaluate the safety of cyclists : Community based, macro-level collision prediction models using negative binomial regression. Accident Analysis and Prevention, 61, 129-137. https:// doi.org/10.1016/j.aap.2012.05.018

Weiler, S. (2006). A park by any other name: National park designation as a natural experiment in signaling. Journal of Urban Economics, 60(1), 96-106. https://doi.org/10.1016/j. jue.2006.02.001.

Windle, J., \& Rolfe, J. (2013). Ocean \& coastal management estimating non-market values of Brisbane (state capital) residents for state based beach recreation. Ocean \& Coastal Management, 85, 103-111. https://doi. org/10.1016/j.ocecoaman.2013.09.011.

Zikmund, W.G. \& Babin, B. J. (2016). Exploring marketing research. (11 ${ }^{\text {th }}$ ed.). Massachusetts: Cengage. 